\title{
West Nile Virus Encephalitis in a Patient with Renal Transplant
}

\author{
Charles-Lwanga Bennin, MD, Steve Krawitz, MD and Emma Weaver, MD
}

\section{Introduction}

Most cases of West Nile Virus infection are asymptomatic. $60 \%$ to $70 \%$ of neuro-invasive cases of West Nile virus infection result in meningitis or encephalitis; however, West Nile encephalitis occurs in less than $1 \%$ of patients infected with the West Nile virus. ${ }^{1}$

\section{Case}

Our patient is a 60 year old Caucasian female with a history of antiphospholipid syndrome, an ischemic stroke in 1994 resulting in warfarin therapy, hypertension, end stage renal disease secondary to idiopathic glomerulonephritis status post cadaveric renal transplant in 1995 on immunosuppressive therapy. She presented with multiple febrile episodes and subjective chills one day prior to admission. She was alert and oriented to person, place and time, but appeared weak. She had no nuchal rigidity and cardiovascular and pulmonary examinations were within normal limits.

On admission she was on the following medications: mycophenolate $1 \mathrm{gm}$ every 12 hours, daily administration of atenolol $25 \mathrm{mg}$, warfarin $4 \mathrm{mg}$ daily, duloxetine $30 \mathrm{mg}$, and lorazepam $0.5 \mathrm{mg}$ as needed for anxiety. She had no known drug allergies. Her family history was unremarkable and she denied the use of alcohol, tobacco, or illegal substances. Laboratory values on admission are presented in Table 1.

She was admitted for fever workup. On hospital day 2, she had a change in mental status, and therapy was initiated for presumptive bacterial and viral meningitis, encephalitis, and bacterial sinusitis. Computed tomography (CT) scan of the head showed encephalomalacia and gliosis in the right posterior frontal lobe and right basal ganglia. There was no new hemorrhage, mass effect, midline shift or edema. With worsening mental status, she was transferred to the intensive care unit (ICU) for closer monitoring. She never required ventilator support. She was later transferred to the general floor after 3 days in the ICU when her mental status improved. She subsequently had an abrupt worsening in her mental status. She also continued to have febrile episodes (Figure 1) A magnetic resonance imaging (MRI) of the brain also revealed cerebral volume loss.

She was re-admitted to the ICU and later transferred to the Neurology ICU (NICU). A lumbar puncture (LP) was performed on hospital day 2,13 and 17. Each sample of cerebrospinal fluid (CSF) was sent for polymerase chain reaction (PCR) (analysis of Mycobacterium tuberculosis, Herpes simplex virus (HSV), Cytomegalovirus and JC virus; Lyme (IgG, IgM), Toxoplasma IgG; fungal, bacterial culture and India ink for Cryptococcus which was all negative.

The ELIZA assay for CSF West Nile virus from hospital day 13 returned positive. The initial West Nile ELISA assay from

\begin{tabular}{|l|c|c|c|}
\hline Table 1. Laboratory Values on Admission \\
\hline Sodium & 134 & $(135-146)$ & $\mathrm{mmol} / \mathrm{L}$ \\
\hline Potassium & 4.0 & $(3.5-5.0)$ & $\mathrm{mmol} / \mathrm{L}$ \\
\hline Chloride & 101 & $(98-109)$ & $\mathrm{mmol} / \mathrm{L}$ \\
\hline CO2 & 24 & $(24-32)$ & $\mathrm{mmol} / \mathrm{L}$ \\
\hline Urea-Nitrogen & 32 & $(7-26)$ & $\mathrm{mg} / \mathrm{dL}$ \\
\hline Glucose & 104 & $(50-100)$ & $\mathrm{mg} / \mathrm{dL}$ \\
\hline WBC & 8.7 & $(4-11)$ & $\mathrm{B} / \mathrm{L}$ \\
\hline HGB & 11.4 & $(12.5-15)$ & $\mathrm{g} / \mathrm{dL}$ \\
\hline HCT & 36.8 & $(36-46)$ & $\%$ \\
\hline Platelet Count & 185 & $(140-400)$ & $\mathrm{B} / \mathrm{L}$ \\
\hline LP & 1 & 2 & 3 \\
\hline CSF Lymphocytes & 23 & 86 & 93 \\
\hline
\end{tabular}

hospital day 2 was negative; however repeat testing on hospital day 13 revealed elevated IgG of 2.03 (normal $<1.3$ ) and elevated IgM of 5.27 (normal <0.9). All antibiotics were stopped on hospital day 22. She later regained her mental status and was almost back to her mental baseline. She was transferred out of the NICU on hospital day 25.

\section{Discussion}

In the West Nile region of northern Uganda the first isolate of an arbovirus was obtained from a febrile woman. The first reported case of West Nile encephalitis was in the early 1950s in New York resulting from an experimental treatment for advanced cancer. ${ }^{1}$ Almost forty years later, in 1999, cases of West Nile encephalitis appeared in clusters in the United States ${ }^{2}$ with multiple cases having been documented thereafter. Typically these cases peak in the warm months of the year in the northeast in the months of July to October. ${ }^{3}$ The West Nile virus is a single stranded RNA flavivirus. The carriers of this virus are usually migratory birds that have been bitten by an infected Culex mosquito (Figure 2).

In most patients infected with the West Nile virus, there is on average a $10 \pm 5$ days incubation period. In a subset of infected individuals such as immunocompromised patients, viral incubation can last up to 21 days. ${ }^{4}$ The most common clinical presentation includes fever with a viral prodrome, however tremors although uncommon can also be seen. ${ }^{5}$ The sensitivity of ELISA to detect West Nile IgM increases based on the timing of the sample, as successful isolation decreases as the disease duration progresses. ${ }^{5}$ In West Nile encephalitis the virus crosses the blood brain barrier and hence detection involves analysis of the CSF. Real time PCR detects the infection in about half of infected patients. ${ }^{6}$ IgM detection is the most common and preferred test of choice. In addition to CSF and serum analysis 


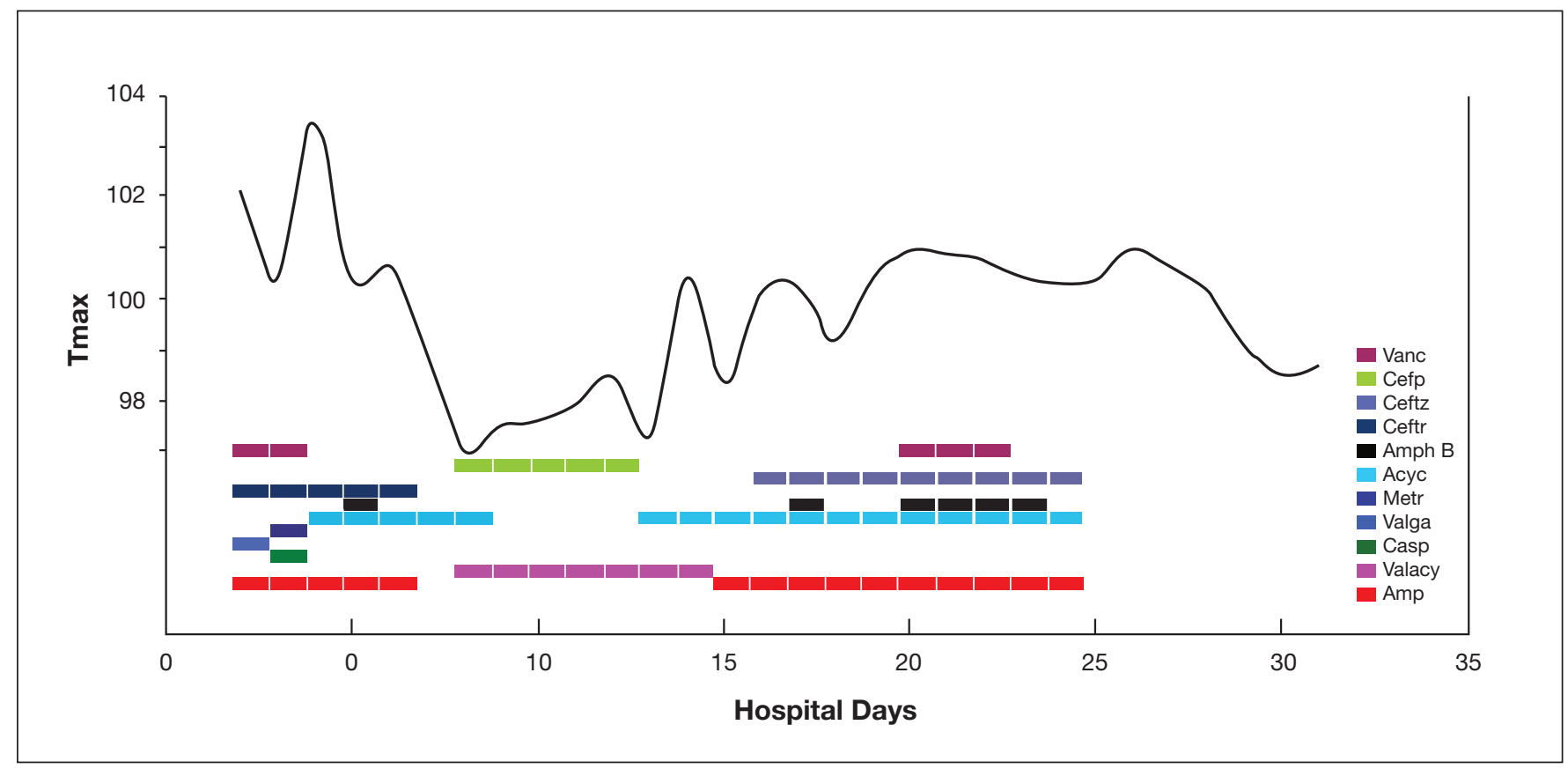

Figure 1. Fever curve

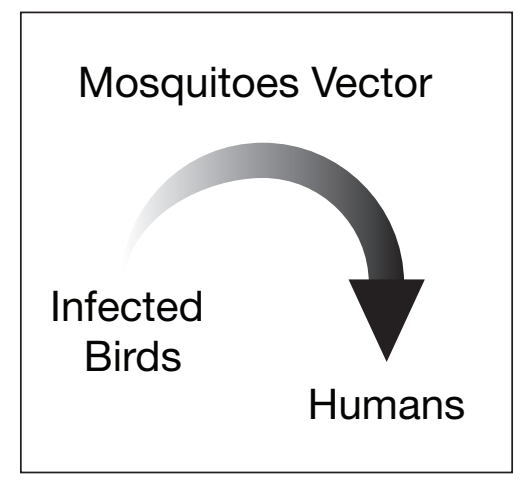

of IgM, imaging modalities such as MRI or CT of the brain may be helpful in identifying the presence of central nervous system inflammation.

\section{Conclusion}

Other causes of encephalitis or meningitis such as HSV and Lyme disease should be ruled out prior to initiating treatment for West Nile encephalitis. As shown in Figure 1, antiviral or antibiotics have no effect on febrile episodes and treatment is generally supportive. Complications such as cerebral edema, headaches can occur after infection. Our patient had residual persistent limb weakness which was managed with physical therapy.

\section{References}

1. Solomon T, Ooi MH, Beasley DW, Mallewa M. West Nile encephalitis. BMJ. 2003Apr 19;326(7394):865-9.

2. Marfin AA, Gubler DJ. West Nile encephalitis: an emerging disease in the United States. Clin Infect Dis. 2001 Nov 15;33(10):1713-9. Epub 2001 Oct 5. Review.

3. Mostashari F, Bunning ML, Kitsutani PT, Singer DA, Nash D, Cooper MJ, Katz N, Liljebjelke KA, Biggerstaff BJ, Fine AD, Layton MC, Mullin SM, Johnson AJ, Martin DA, Hayes EB, Campbell GL. Epidemic West Nile encephalitis, New York, 1999: results of a household-based seroepidemiological survey. Lancet. 2001 Jul 28;358(9278):261-4.

4. Iwamoto M, Jernigan DB, Guasch A, Trepka MJ, Blackmore CG, Hellinger WC, Pham SM, Zaki S, Lanciotti RS, Lance-Parker SE, DiazGranados CA, Winquist AG, Perlino CA, Wiersma S, Hillyer KL, Goodman JL, Marfin AA, Chamberland ME, Petersen LR; West Nile Virus in Transplant Recipients Investigation Team. Transmission of West Nile virus from an organ donor to four transplant recipients. N Engl J Med. 2003 May 29;348(22):2196-203.

5. Hayes CG. West Nile Fever. In: Monath TP, ed. The arboviruses: epidemiology and ecology. Vol 5. Boca Raton, FL: CRC Press, 1989:59-88.

6. Lanciotti RS, Kerst AJ, Nasci RS, Godsey MS, Mitchell CJ, Savage HM, Komar N, Panella NA, Allen BC, Volpe KE, Davis BS, Roehrig JT. Rapid detection of west nile virus from human clinical specimens, field-collected mosquitoes, and avian samples by a TaqMan reverse transcriptase-PCR assay. J Clin Microbiol. 2000 Nov;38(11):4066-71. 